\title{
無収縮高流動コンクリートで一体化した逆打ちコンクリートの 打継ぎ部の力学性状に関する研究 \\ MECHANICAL BEHAVIOR OF HORIZONTAL JOINT INVERSELY CAST WITH SHRINKAGE COMPENSATING HIGH FLUIDITY CONCRETE
}

\author{
石原 誠一郎*1, 三橋博三*2, 金子佳 生*3, 立松和 彦*1, 山㠃順二*1 \\ Seiichiro ISHIHARA, Hirozo MIHASHI, Yoshio KANEKO, \\ Kazuhiko TATEMATSU and Junji YAMASAKI
}

\begin{abstract}
Shrinkage compensating high fluidity concrete is a new type of concrete for construction joints which enables the joint to bond firmly in the inverse placing construction method. With the aim of examining mechanical behavior in horizontal joint inversely cast with shrinkage compensating high fluidity concrete, the bending test and shear test were conducted. As the result, it has become clear that the flexural strength and shearing strength of horizontal joint inversely cast with shrinkage compensating high fluidity concrete is equal to the strength of the construction joint of normal placing method.
\end{abstract}

Keywords : shrinkage compensating high fluidity concrete, inverted constmuction method, construction joint, flexural strength, shearing strength 無収縮高流動コンクリート，逆打ち，打継ぎ，曲げ強度，せん断強度

\section{1. はじめに}

コンクリート構造物の逆打ち工法における打継ぎ処理法は；長い 間研究，改善が加えられ多くの工法が提案されてきたが，未だ標準 化されるに至っていないのが現状である ${ }^{3)}$ 。逆打ちコンクリート工法 の打継ざ処理方法として, 先打ちコンクリートの下面に後打ちコン クリートを直接付着させる直接法がある。しかし，後打ちコンクリ 一トの材料分離やブリーディングによる沈下が生じ，打継ぎ処理方 法として問題があった。その問題点を改善する方法として，無収縮 モルタルの充填法や，セメントペーストや樹脂の注入法などの工法 が提案され実施されてきた ${ }^{4}$ 。

一方, 逆打継ぎ部の力学性状の研究は, 逆打ちと一体打ちの構造 性能を部材レベルで比較する研究 5) の) が主で，逆打継ぎ部のコンク リートのみの曲げおよびせん断応力下での力学性状についての研究 は少ない ${ }^{8)}$ 。特に, せん断応力下での力学性状については, 逆打継ぎ 部を鉄筋で補強した試験体による実験9110)がほとんどで, 鉄筋の影 響を除いたコンクリートのせん断举動は十分明らかにされていない。 逆打継ざ部のコンクリートの力学性状について研究が少ない背景に は，逆打継ざ部を一体化できるようなコンクリートが少なく，逆打 継ぎ部に隙間が出来る事を前提として，その陌間をモルタルやセメ ントペーストで詰める対応が取られているためと考えられる。

筆者らは，高流動コンクリートにアルミニウム粉末，膨張材，乾 燥収縮低隇剤等を主成分とする混和材料を添加し，各混和材料の機 能により，高い流動性と材料分離抵抗性及び適度の発泡作用之膨張
作用により打設後の沈下と収縮を補偵して，逆打継ざ部のコンクリ 一トの一体性の確保を実現することを目的として新たな打継ぎコン クリートを提案してきた ${ }^{11)}$ (12)。この打継ぎコンクリートを以下，無 収縮高流動コンクリートと呼ぶ。本研究では, 無収縮高流動コシク リートを逆打ちした打継ぎ部の力学性状について述べる。

まず，無収縮高流動コンクリートを逆打ちした供試体の打継ざ部 の曲げ付着性状を，日本コンクリート工学協会（JCI）の「コンクリ 一トの破壊特性の試験方法に関する調查研究委員会」において提案 されたプレーンコンクリートの破壊エネルギー試験法案 ${ }^{13)}$ に基づい た試験により評価し，一体打ち，順打ちによる供試体と比較した結 果を述べる。次に，打継ざ部のコンクリートのせん断性状をより精 密に評価する試験方法を新たに提案し，無収縮高流動コンクリート を逆打ちした試験体の打継ぎ部のせん断挙動を，一体打ち，順打ち および無収縮モルタルの充填法による試験体と比較することで，そ の一体性を検証した結果について述べる。

\section{2. 無収縮高流動コンクリートの開発コンセプト}

逆打継ぎ部の先打ちコンクリートと後打ちコンクリートが一体と なりにくい原因として，以下のような要因が考えられる。

1） 後打ちコンクリートのブリーディングによる沈下

2）先打ちコンクリート下面への後打ちコンクリートの付着が不 十分であること

3）後打ちコンクリートの硬化後の乾燥収縮

\footnotetext{
本論文は，参考文献1)2)の内容を加篗，修正したものである。

*1. 淺沼組技術研究所

*2 東北大学大学院工学研究科都市・建築学専攻 教授・工博

*3 東北大学大学院工学研究科都市·建築学専攻 助教授 $\cdot \mathrm{Ph}$. D.
}

Technical Research Institute, Asanuma Corporation

Prof., Dept. of Architecture \& Building Science, Graduate School of Engineering, Tohoku University, Dr. Eng.

Assoc. Prof., Dept. of Architecture \& Building Science, Graduate School of Engineering, Tohoku University, Ph. D. 
これらの問題点を解決するため, 無収縮高流動コンクリートには 図 1 に示す混和材料を添加しコンクリートに以下の機能を持たせた。

1）流動性の良い, 分離抵抗性の高い高流動コンクリートとする。

2) アルミニウム粉末（以下，AL粉末と略記する）を添加しフレ ッシュコンクリートを膨張させることで, ブリーディングによ る沈下を補償し，打継ぎ面への付着性を向上させる。

3）コンクリートに膨張材, 乾燥収縮低減剤を添加し, 硬化後の コンクリートの乾燥収縮を補償する。

なお，無収縮高流動コンクリートの基本物性については参考文献 11）に実大施工実験の結果については参考文献 12)に発表している。

\section{3. 曲げ実験}

\section{1 供試体}

供試体の形状を図 2 に示す。供試体の寸法は $10 \times 10 \times 40 \mathrm{~cm}$ とし た。供試体の中央にコンクリートカッターで幅 $3 \mathrm{~mm}$ ，高さ $50 \mathrm{~mm}$ の 切欠きを設けた。供試体一覧を表 1 に示す。使用コンクリートの種 類は普通コンクリート（C01， C02） と水結合材比の異なる 2 種類の 無収縮高流動コンクリート（SHA，SHB）である。打継ぎ方法は一 体打ち, 順打ち, および逆打ちの 3 種類, 打継ぎ面は平滑面とした。

\section{2 コンクリートの調合と使用材料}

使用材料を表 2 に，各コンクリートの調合を表 3 に示す。各材料 試験結果を表 4 に示す。各供試体は図 3 に示すように製作した。打 継ざ供試体は，まず先打ち部の普通コンクリートを打設した。打継 ぎ面は塗装合板による平滑仕上げとした。約 2 週間後に，順打ち供 試体の後打ち部に普通コンクリートを打設し，逆打ち供試体の後打 ち部には無収縮高流動コンクリートを打設した。無収縮高流動コン クリートの AL 粉末の発泡による最大自由膨張率は SHA が 1.78\%, SHBが $1.21 \%$ であった。SHA，SHB の自由膨張率の経時変化を図 4 に示す。なお，SHA，SHBおよび市販の無収縮モルタルについて拘 束膨張収縮試験（JIS A 6202）を行った。図 5 に示すように無収縮 モルタルに比べて, 硬化後の乾燥収縮が極めて小さいことを確認し た。なお，曲げ試験は材齢約 1 年で行った。

\section{3 試験方法}

試験装置の概要を図 2 に示す。載荷には容量 $200 \mathrm{kN}$ のサーボパル サ用アクチュエータを用いた。載荷は $0.002 \mathrm{~mm} / \mathrm{sec}$ の一定速度でア クチュエータのヘッドを変位制御しながら載荷した。データのサン プリングは 5 回秒とした。破壊エネルギ一試験法 (案) ${ }^{13)}$ に準じて， ひび割れ開口変位（CMOD）をクリップゲージにより計測した。

\section{4 実験結果および考察}

代表的な供試体の荷重と CMOD との関係を図 6 に示す。普通コン クリートの一体打ち UJT1，UJT2 と無収縮高流動コンクリートの一 体打ち SHA，SHB とを比較した荷重と CMOD との関係のうち全体 を（a）に，開口変位 $0.5 \mathrm{~mm}$ までの関係を（b）に示す。無収縮高流 動コンクリートは普通コンクリートにくらべ高強度であるため, SHA，SHB は UJT1，2にくらべ高いピーク荷重值を示した。

\begin{tabular}{|c|c|c|}
\hline 混和材料撞成 & & 各混和材料の機能 \\
\hline (1)腟張材 & $\Rightarrow$ & |コンクリート硬化後の乾㗚収縮を補情 \\
\hline (2)高性能 AE 減水戍 & $\Rightarrow$ & 高い減水性能及び良好なスランプ保持性 \\
\hline (3)ルミニウム粉末 & $\Rightarrow$ & ブリーディンクによる沈降を補柾する \\
\hline (4)乾㘿収缩低隇剈 & $\Rightarrow$ & コンクリート硬化後の乾箱収缩を補侻 \\
\hline
\end{tabular}

図 1 無収縮高流動コンクリートの混和材料構成とその機能
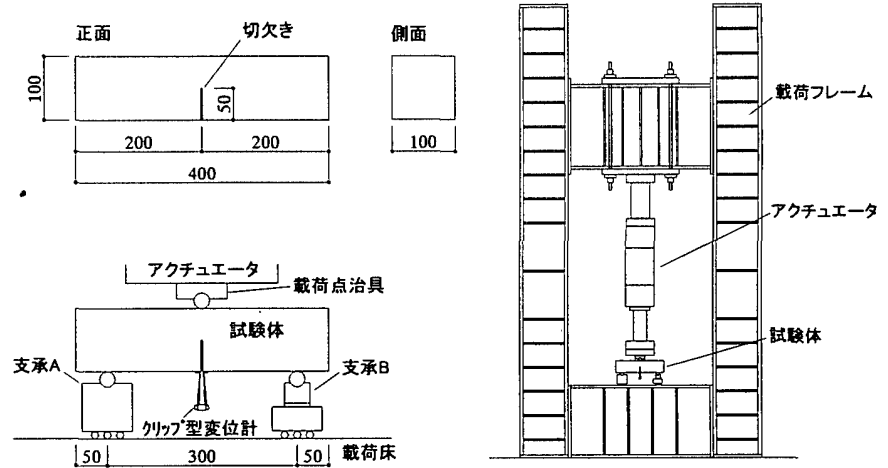

図 2 供試体および試験装置

表 1 供試体一覧

\begin{tabular}{|c|c|c|c|c|}
\hline $\begin{array}{c}\text { 供試体 } \\
\text { 記号 }\end{array}$ & 種類 & $\begin{array}{l}\text { 打継 } \\
\text { ぎ面 }\end{array}$ & $\begin{array}{l}\text { 供試 } \\
\text { 体数 }\end{array}$ & 使用 CON \\
\hline UJT1 & 一体打ち & $=$ & 3体 & $\mathrm{C} 01$ \\
\hline UJT2 & 一体打ち & - & 5 体 & $\mathrm{C} 02$ \\
\hline SHA & 一体打占 & $\overline{-}$ & 5 体 & SHA \\
\hline SHB & 一体打亏 & $=$ & 5 体 & SHB \\
\hline JPT & 順打継き & 平滑 & 4 体 & $\mathrm{C} 01$ (先打ち) $+\mathrm{C} 02$ (後打 5$)$ \\
\hline JIPTA & 逆打継き & 平滑 & 5 体 & $\mathrm{CO2}$ (先打ち) + SHA（後打 5$)$ \\
\hline JIPTB & 逆打継き & 平滑 & 5 体 & $\mathrm{C} 02$ (先打ち) + SHB (後打ち) \\
\hline
\end{tabular}

表 2 使用材料

\begin{tabular}{|c|c|}
\hline 材料 & 規格・性状 \\
\hline セメント & 普通ポルトランドセメント 密度 $3.16 \mathrm{~g} / \mathrm{cm}^{3}$ \\
\hline 細骨材 & $\begin{array}{l}\text { 山砂(城陽産) 表乾密度 } 2.56 \mathrm{~g} / \mathrm{cm}^{3} \\
\text { 粗粒率 } 2.80 \text { 吸水率 } 1.96 \%\end{array}$ \\
\hline 粗骨材 & 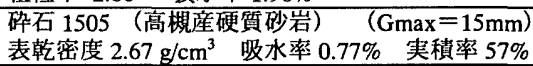 \\
\hline 分離低滅剤 & セルロース系 \\
\hline 発泡剂 & 特殊処理アルミニウム粉末 \\
\hline 膨張材 & 石灰系 \\
\hline 収縮低減剤 & 低級アルコールアルキレンオキシド付加物 \\
\hline $\begin{array}{l}\mathrm{AE} \text { 減水剂 } \\
\text { 高性能 } \mathrm{AE} \text { 诚水剂 }\end{array}$ & 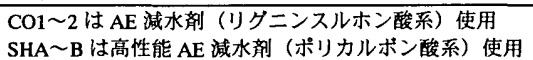 \\
\hline
\end{tabular}

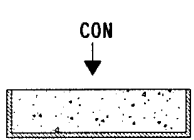

一体打与供試体

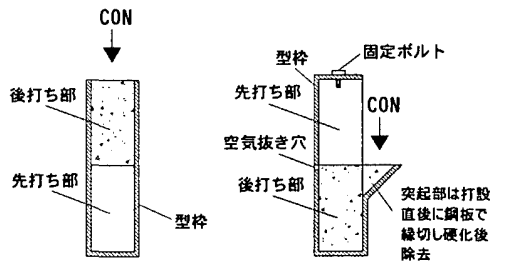

㮌打継き供試体逆打繾ぎ供試体

図 3 供試体作製要領

表 4 材料試験結果

\begin{tabular}{c|c|c|c|c|c}
\hline $\begin{array}{c}\mathrm{CON} \\
\text { 記号 }\end{array}$ & $\begin{array}{c}\text { スランプ } \\
\text { フロー }(\mathrm{cm})\end{array}$ & $\begin{array}{c}\text { 最大自由 } \\
\text { 膨張率 }(\%)\end{array}$ & $\begin{array}{c}\text { 圧縮強度 } \\
\left(\mathrm{N} / \mathrm{mm}^{2}\right)\end{array}$ & $\begin{array}{c}\text { 割裂強度 } \\
\left(\mathrm{N} / \mathrm{mm}^{2}\right)\end{array}$ & $\begin{array}{c}\text { 静弾性係数 } \\
\left(\mathrm{kN} / \mathrm{mm}^{2}\right)\end{array}$ \\
\hline $\mathrm{C} 01$ & - & - & 29.7 & 2.43 & 29 \\
\hline C02 & - & - & 35.5 & 2.63 & 27 \\
\hline SHA & $54 \times 52$ & 1.78 & 56.0 & 4.30 & 36.2 \\
\hline SHB & $57 \times 56$ & 1.21 & 65.9 & 4.10 & 37.7 \\
\hline
\end{tabular}

表 3 調合表

\begin{tabular}{|c|c|c|c|c|c|c|c|c|c|c|c|}
\hline $\begin{array}{l}\text { CON } \\
\text { 種類 }\end{array}$ & $\begin{array}{l}\text { W/B } \\
(\%)\end{array}$ & $\begin{array}{c}\mathrm{s} / \mathrm{a} \\
(\%)\end{array}$ & $\begin{array}{c}\text { 水 } \\
(\mathrm{kg})\end{array}$ & $\begin{array}{c}\text { セxント } \\
(\mathrm{kg})\end{array}$ & $\begin{array}{c}\text { 膨張材 } \\
(\mathrm{kg})\end{array}$ & $\begin{array}{c}\begin{array}{c}\text { 細骨材 } \\
(\mathrm{kg})\end{array} \\
\end{array}$ & $\begin{array}{c}\text { 粗骨材 } \\
(\mathrm{kg})\end{array}$ & $\begin{array}{c}\text { 分離低減郕 } \\
(\mathrm{kg})\end{array}$ & $\begin{array}{c}\text { 収縮低減剂 } \\
(\mathrm{kg})\end{array}$ & $\begin{array}{c}\text { AL 粉末 } \\
(\mathrm{g})\end{array}$ & $\begin{array}{c}\text { (高性能) } \\
\mathrm{AE} \text { 減水剂 }(\mathrm{kg}) \\
\end{array}$ \\
\hline $\mathrm{C} 01,02$ & 60 & 51.1 & 186 & 310 & - & 878 & 876 & - & - & - & 3.29 \\
\hline SHA & 45 & 51.4 & 180 & 370 & 30 & 847 & 836 & 0.36 & 7.5 & 21.5 & 5.6 \\
\hline SHB & 35 & 51.0 & 175 & 465 & 35 & 806 & 806 & - & 10 & 21.5 & 5.3 \\
\hline
\end{tabular}




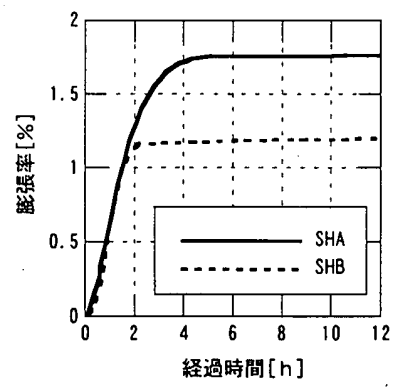

図 4 自由膨張率の経時変化

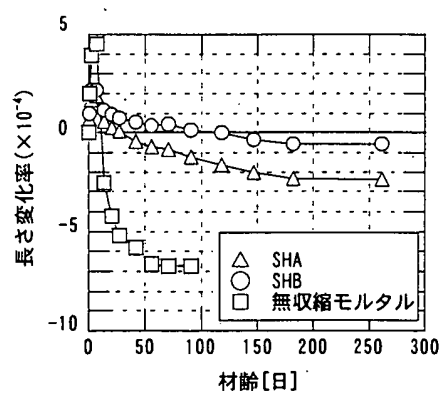

図 5 拘束膨張収縮試験結果

順打ちした JPT と, SHA, SHB を逆打ちした JIPTA およびJIPTB とを比較した荷重と CMOD との関係のうち全体を（c）に，開口変 位 $0.5 \mathrm{~mm}$ までの関係を（d）に示す。逆打ちした供試体は順打ちと 同様な荷重一CMOD 関係を示した。

破壊エネルギー $\mathrm{G}_{\mathrm{F}}$ （単位面積あたりのひび割れを形成するるのに必 要なエネルギー) と破断時 CMOD との関係を図 7 に, 曲げ強度と最 大荷重時 CMOD との関係を図 8 に示す。図 7 から一体打ちにくらべ 打継ぎ供試体の $\mathrm{G}_{\mathrm{F}}$ が非常に小さいことがわかる。一方, 逆打ちと 順打ちの打継ぎ供試体の $\mathrm{G}_{\mathrm{F}}$ はほとんど差がなく, さらに逆打ちした JIPTA と JIPTB の $\mathrm{G}_{\mathrm{F}}$ にも明確な差は認められなかった。

次に, 一体打ちと打継ぎ供試体の曲げ強度を比較すると, 打継ぎ 供試体は一体打ちにくらべ曲げ強度が低くなっているが, その減少 の程度は $\mathrm{G}_{\mathrm{F}}$ ほど大きくない。逆打ちと順打ちの供試体の一体打ちに 対する曲げ強度比を図 9 に示す。一体打ちの $40 \%$ 程度しか曲げ強度 がない順打ち JPT に比べ, 逆打ち供試体の曲げ強度比の方が少し大 きく, 特に JIPTA の曲げ強度比は $60 \%$ 以上と高かった。材齢約 1 年 時の試験で, さらに逆打ちにもかかわらず順打ちと同等以上の曲げ 強度を示したのは, 無収縮高流動コンクリートが $\mathrm{AL}$ 粉末によりフ レッシュ時に膨張し, 逆打継ぎ面に十分付着し, さらに硬化後の乾 燥収縮が小さいためと考えられる。写真 1 に JIPTA と JPT の破面状 況を示す。JPTA はJPTにくらべ破面の凹凹が激しく一体性が高い ことがわかる。逆打ち供試体のうちJIPTA はJIPTB に打継いだ SHB よりも低強度の SHA を打継いだにもかかわれず, 曲げ強度が高かっ た原因は，打継いだ SHA の AL 粉末による膨張が SHB よりも大き く打継ぎ面に十分付着したためと考えられる。

\section{4. せん断実験}

\section{1 試験体}

試験体一覧を表 5 に示す。試験体は打継ぎ方法と打継ぎ面の処理 法を変えた 7 種類で, 合計 17 体とした。打継ぎ方法は直接法（逆打 ち), 一体打ち, 順打ち, 充填法の 4 種類, 打継ぎ面の処理法は平滑 面と目荒し面の 2 タイプとした。試験体形状は各試験体とも同じで, その詳細を図 10 に示す。従来の間接一面せん断試験では, 破壊想定 断面に鉄筋を配した場合，鉄筋のダウエル作用の影響を受け，コン クリートのみのせん断挙動を把握することが難しい。そのため, 今 回の試験法では各試験体に 4 本の拘束用鋼棒（鋼棒直径 $8 \mathrm{~mm}$ ）をシ 一スに通し打継ぎ面に直交するように配置し，せん断破壊後の骨材 かみ合い段階の挙動も把握できるようにした。シースの直径を鋼棒 直径よりも $5 \mathrm{~mm}$ 大きくし, 鋼棒によるダウエル作用と不必要なせん

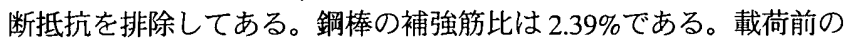
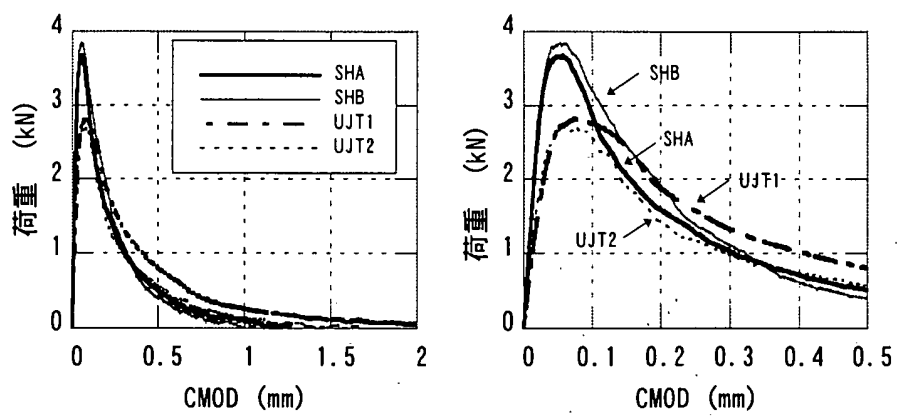

(a) 全体

（b）拡大図（開口変位 $0.5 \mathrm{~mm}$ まで）
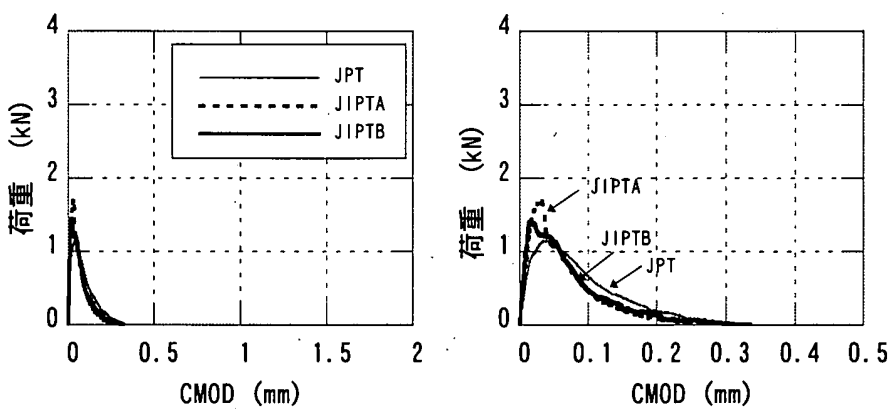

(c) 全体

（d）拡大図（開口変位 $0.5 \mathrm{~mm}$ まで） 図 6 荷重 - CMOD 曲線

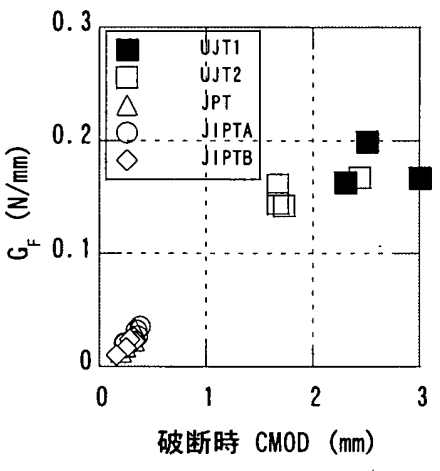

図 $7 \quad G_{F}-C M O D$

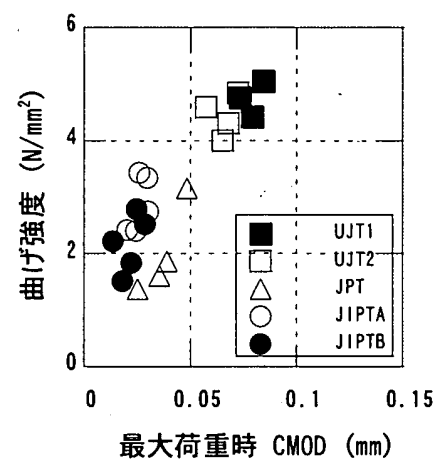

図 8 曲げ強度一CMOD

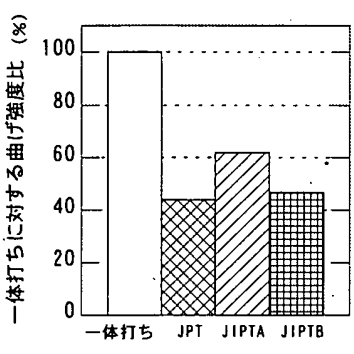

図 9 曲げ強度比

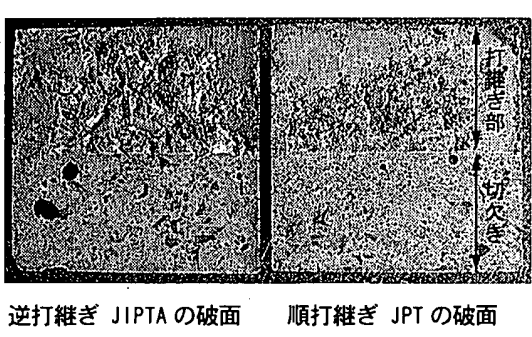

写真 1 破面状況の比較
鋼棒の拘束は，鋼棒を所定位置に配するためナットを軽く手締めす る程度にして，ほとんど拘束力をかけないようにした。さらに打継 ぎ面で確実にせん断破壊を起こすよう，打継ぎ面の上下左右にV字 形の溝を切った。試験体の打継ぎ面積は $78.3 \mathrm{~cm}^{2} \quad(8.9 \mathrm{~cm} \times 8.8 \mathrm{~cm})$ である。一体打ちの試験体にも同じ位置で溝を切り, 破壊想定面積 が打継ぎ面積と同じになるようにした。

各試験体は図 11 に示すように製作した。まず，一体打ちを除く試 験体の先打ち部に普通コンクリント C03 を打設した。剥離用テープ 
を巻いた丸鋼を打ち込み，硬化直前に丸鋼を引抜き鋼棒用のシース を作製した（図11（a）〜 (c) の(1)(2)参照)。平滑面タイプは打継ぎ 面を塗装合板による仕上げとし, 目荒しタイプは打継ぎ面に凝結遅 延シートを貼付け, 材齢 7 日に目荒しを行った。材齢 14 日に順打ち の後打ち部と一体打ちの普通コンクリート C04 を同時に打設し, 直 接法試験体の後打ち部に無収縮高流動コンクリートを打設した（図 11 (a)（b）の3(4)参照)。その翌日に充填法試験体の後打ち部に無 収縮モルタルを充填した。充填法の無収縮モルタルには，市販のプ レミックス無収縮モルタルを用いた (図 11 (c) の(3)(4)参照)。なお, 後打ち部および一体打ちにも先打ち部と同様に丸鋼を打ち込み，硬 化前に引抜き，鋼棒用のシースを作製した（図 11 (d) (1)〜(3)参照)。

\section{2 コンクリートの調合と使用材料}

先打ち部, 後打ち部および一体打ち試験体に用いた普通コンクリ 一ト CO3 と 04, 無収縮高流動コンクリートSHF の調合を表 6 に示 す。SHF の調合は SHA に準じた調合で W/B を若干高くしている。 使用材料は表 2 と同じである。無収縮高流動コンクリートを直接法 で打継いだ試験体は打設高さが $100 \mathrm{~mm}$ と小さく, 打継ぎ面への無収 縮高流動コンクリートの付着が不十分になる恐れがあったため目標 膨張率を $2.5 \%$ 程度になるよう $\mathrm{AL}$ 粉末を添加した。

\section{3 コンクリート表面粗さの測定方法}

打継ぎ部の目荒し程度を数值化する目的で打継ぎ面の表面粗さを レーザー変位計で $0.1 \mathrm{~mm}$ 間隔で計測した。表面粗さを定量的に示す 粗さの定義はJIS B 0601 の中心線平均粗さRaによった(図 12 参照)。

\section{4 試験方法}

試験は図 13 に示す $100 \mathrm{kN}$ コンピュータ計測制御式精密万能試験 機を用い，せん断ひび割れを起すまで $0.005 \mathrm{~mm} / \mathrm{min}$ ，ひび割れ発生

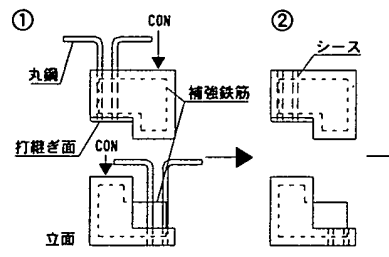

(3)

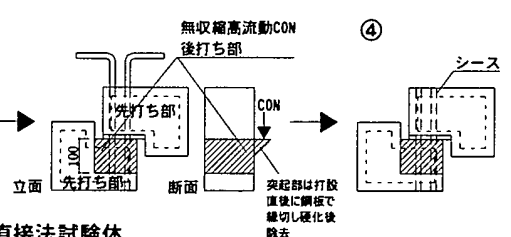

(a) 直接法試雅体

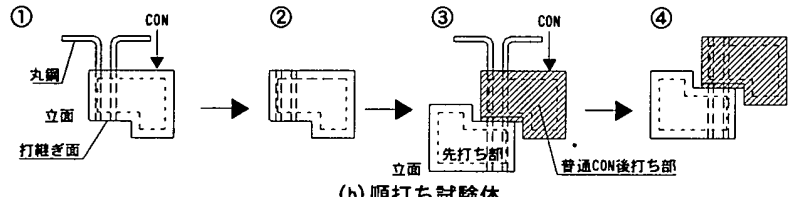

(b) 順打与試酸体

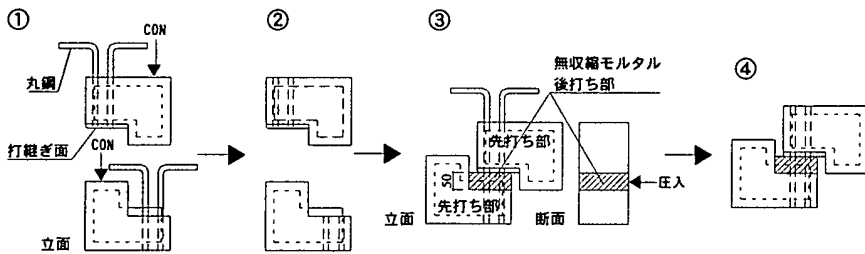

(c) 充填法試桧体

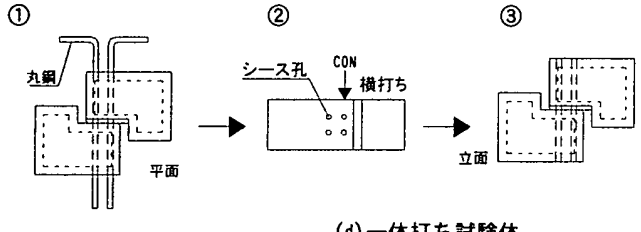

(d)一体打与試呀体

図 11 試験体製作要領
表 5 試験体一覧

\begin{tabular}{|c|c|c|c|}
\hline $\begin{array}{l}\text { 羾倹体 } \\
\text { 記号 }\end{array}$ & $\begin{array}{c}\text { 打継き } \\
\text { 方法 }\end{array}$ & $\begin{array}{l}\text { 打䋛き”面 } \\
\text { 処理法 }\end{array}$ & 打継ぎ材料 \\
\hline SHFP1 & 直接法 & 平滑面 & 無収縮高流軼コンクリート \\
\hline SHFP2 & 直接法 & 平滑面 & 無収樎高流動コンクリート \\
\hline SHFP3 & 直接法 & 平滑面 & 無収縮高流動コンクリート \\
\hline SHFM1 & 直接法 & 目荒し & 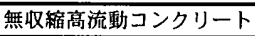 \\
\hline SHFM2 & 直接法 & 目荒し & 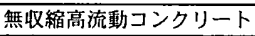 \\
\hline SA1 & 一体打与 & - & 普通 CON \\
\hline $\mathrm{SA} 2$ & 一体打占 & - & 普通 $\mathrm{CON}$ \\
\hline $\mathrm{SA3}$ & 一体打占 & - & 普通 CON \\
\hline SBP1 & 順打ち & 平滑面 & 普通 $\mathrm{CON}$ \\
\hline SBP2 & 順打与 & 平滑面 & 普通 CON \\
\hline SBP3 & 順打占 & 平滑面 & 普通 CON \\
\hline SBM1 & 順打占 & 目荒し & 普通 CON \\
\hline SBM2 & 順打ち & 目荒し & 普通 CON \\
\hline SCP1 & 充填法 & 平滑面 & 無収縮モルタル \\
\hline SCP2 & 充填法 & 平滑面 & 無収縮モルタル \\
\hline SCM1 & 充填法 & 目荒し & 無収縮モルタル \\
\hline$\overline{\mathrm{SCM} 2}$ & 充填法 & 目荒し & 無収縮モルタル \\
\hline
\end{tabular}
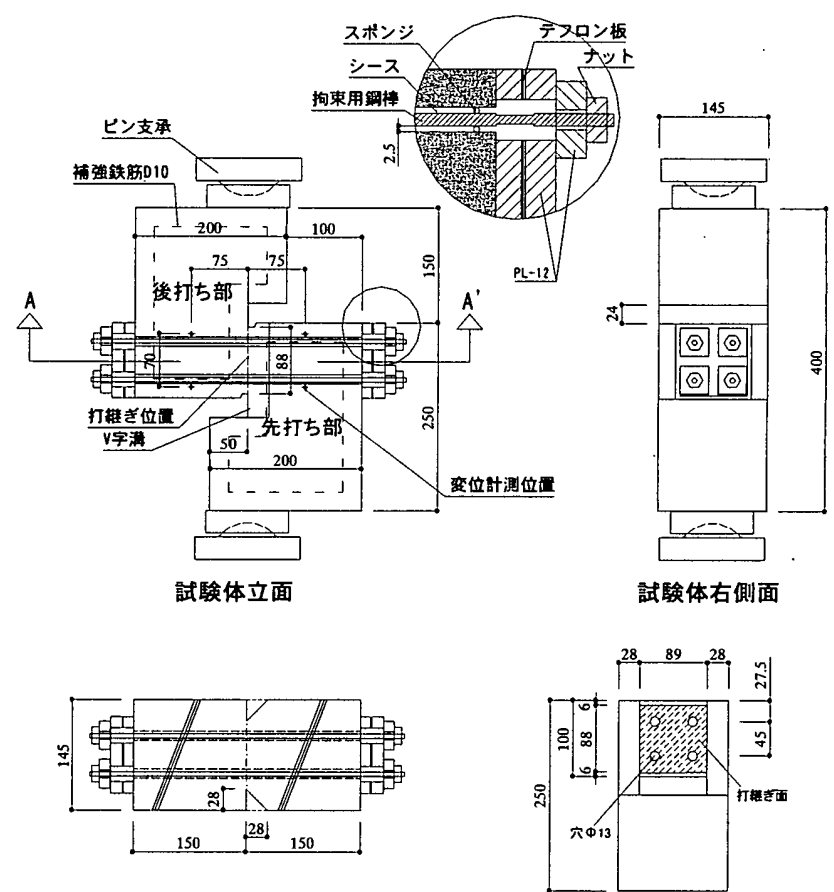

$\mathrm{AA}^{\prime}$ 断面

打継き面詳細

図 10 試験体形状と計測位置
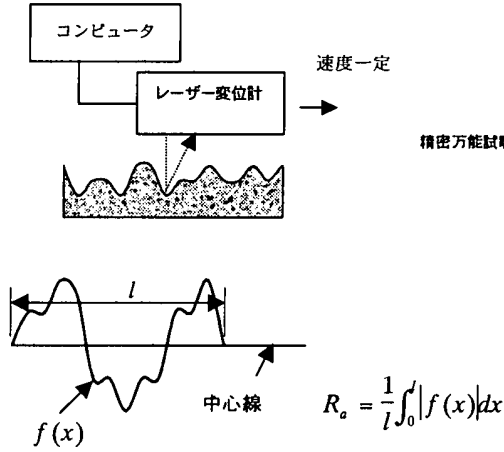

図 12 表面粗さ計測法とRa の定義

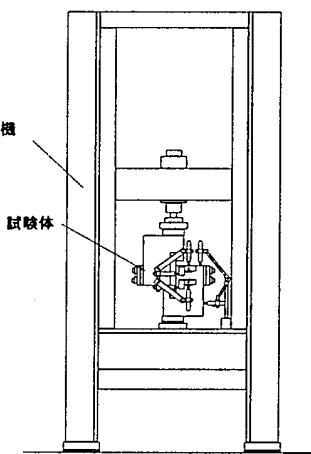

図 13 載荷装置

表 6 調合表

\begin{tabular}{|c|c|c|c|c|c|c|c|c|c|c|}
\hline $\begin{array}{l}\text { CON } \\
\text { 種類 }\end{array}$ & $\begin{array}{c}\mathbf{W} / \mathbf{B} \\
(\%)\end{array}$ & $\begin{array}{l}\text { 水 } \\
(\mathrm{kg})\end{array}$ & $\begin{array}{l}\text { セx } \\
\text { ント } \\
(\mathrm{kg})\end{array}$ & $\begin{array}{c}\text { 瞦張 } \\
\text { 材 } \\
(\mathrm{kg}) \\
\end{array}$ & $\begin{array}{c}\text { 細骨 } \\
\text { 材 } \\
(\mathrm{kg}) \\
\end{array}$ & $\begin{array}{c}\text { 粗骨 } \\
\text { 材 } \\
(\mathrm{kg}) \\
\end{array}$ & $\begin{array}{c}\text { 分離 } \\
\text { 低減郕 } \\
(\mathrm{kg})\end{array}$ & $\begin{array}{c}\text { 収縮 } \\
\text { 低隇用 } \\
(\mathrm{kg}) \\
\end{array}$ & $\begin{array}{l}\mathrm{AL} \\
\text { 汾末 } \\
(\mathrm{g})\end{array}$ & $\begin{array}{c}\text { (滈性能) } \\
\mathrm{AE} \text { 減水绪 } \\
(\mathrm{kg})\end{array}$ \\
\hline $\mathrm{C} 03,04$ & 60 & 189 & 315 & - & 867 & 888 & - & - & - & 0.788 \\
\hline SHF & 47 & 180 & 353 & 30 & 832 & 890 & 0.36 & 10 & 28.75 & 2.0 \\
\hline
\end{tabular}


表.7材料試験結果

\begin{tabular}{|c|c|c|c|}
\hline 使用材料種類 & $\begin{array}{l}\text { 压縮強度 } \\
\left(\mathrm{N} / \mathrm{mm}^{2}\right)\end{array}$ & $\begin{array}{c}\text { 割裂引張強业 } \\
\left(\mathrm{N} / \mathrm{mm}^{2}\right)\end{array}$ & $\begin{array}{c}\text { 静弹性係数 } \\
\left(\mathrm{kN} / \mathrm{mm}^{2}\right)\end{array}$ \\
\hline 先打ち部普通 CON（C03） & 30.1 & 2.4 & 24 \\
\hline 後打ち部普通 $\mathrm{CON}(\mathrm{CO} 4)$ & 26.5 & 2.2 & 23 \\
\hline 無収縮高流動 CON & 34.7 & 3.5 & 26 \\
\hline 無収縮モルタル & 75.5 & 3.7 & 27 \\
\hline
\end{tabular}

後には, $0.06 \mathrm{~mm} / \mathrm{min}$ の速度で載荷した。データサンプリン グは 0.5〜 1 回/秒とした。各試験体の変位計測位置間のせん 断応力, せん断変位およびひび割れ幅の変化を測定した。

\section{5 実験結果および考察}

使用した材料の材料試験結果を表 7 に示す。後打ちした無収縮高 流動コンクリートの最大自由膨張率は $2.89 \%$ であった。せん断試験 は, 後打ち部の普通コンクリート打設後, 7 週経過した時点で行っ た。せん断試験結果の一覧を表 8 に示す。すべての試験体が V字溝 を切った破壊想定位置でせん断破壊した。

（1）せん断応力度とせん断変位の関係

打継ぎ面が平滑な代表的試験体のせん断応力度とせん断変位の 関係を図 14 (A）に，打継ぎ面を目荒したものと一体打ちの代表的 試験体のせん断応力度とせん断変位の関係を図 14（B）に示す。

各試験体とも弾性変形後, 破壊想定位置でせん断ひび割れが発生 し，急激に滑り破壊を起しせん断応力を低下させ安定した骨材かみ 合い段階へと遷移した。なお，図 14 において び割れ強度とは弾性変形後, 破壊想定位置でせん断ひび割れが目視 で確認された時点での応力度である。○で示された骨材かみ合い開 始時せん断強度とは, 滑り破壊後, 骨材かみ合いを開始した時点で の応力度である。なお，表 8 にある最大せん断強度とは, 計測され たせん断応力度とせん断変位の関係の中で最大の応力度を意味する。 打継ぎ試験体では，せん断ひび割れ強度が最大せん断強度であった が，一体打ちの試験体は滑り破壊後のせん断応力の低下が小さく， 骨材かみ合い開始後も応力の上昇が見られたため, 最大せん断強度 はせん断ひび割れ時ではなく，骨材かみ合い段階時に得られた。

（2）せん断ひび割れ強度と表面粗さ（Ra）との関係

図 15 にせん断ひび割れ強度. $\tau_{\mathrm{ci}}$ と表面粗さ Ra との関係を示す。 平滑面に無収縮高流動コンクリートを逆打ちした試験体 SHFP のせ ん断ひび割れ強度は，平滑面に普通コンクリートを順打ちした試験 体 SBP および 部分の普通コンクリートの一体打ちのせん断ひ び割れ強度よりも高くなっている。逆打ちにもかかわらず順打ち以 上のせん断ひび割れ強度を示したのは, 無収縮高流動コンクリート が $\mathrm{AL}$ 粉末によりフレッシュ時に膨張し，逆打継ぎ面に十分付着し たためと考えられる。さらに，一体打ち以上の強度を示したのは， これまでに膨張材を添加することでひび割れ抵抗性が向上すること

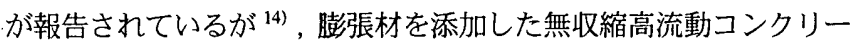
トのひび割れ抵抗性が向上したためではないかと考えられる。一方， 目荒し面を逆打ちした SHFM のせん断ひび割れ強度はSBM と同等 であるが, SHFPよりも少し小さくなっている。これは，無収縮高流 動コンクリートの打設高さが $10 \mathrm{~cm}$ と小さいため, $\mathrm{AL}$ 粉末による膨 張高さが小さく, 目荒し面への無収縮高流動コンクリートの付着が 平滑面より不十分であった事が原因ではないかと考えられる。

充填法による試験体 SCP, SCM のせん断ひび割れ強度は, 他の試 験体にくらべかなり小さかった。これは，試験後の破面観察から，

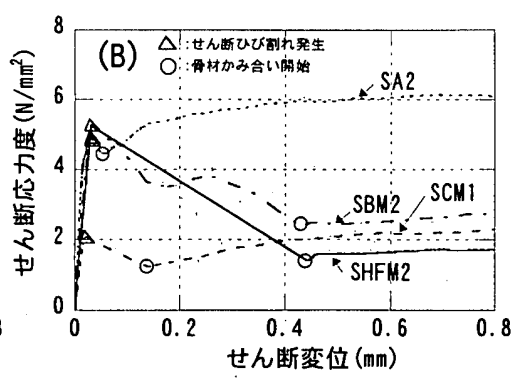

図 14.せん断応力度とせん断変位の関係 表 8 試験結果一覧

\begin{tabular}{|c|c|c|c|c|c|c|c|}
\hline $\begin{array}{l}\text { 試験体 } \\
\text { 記号 }\end{array}$ & $\begin{array}{l}\text { 中心線 } \\
\text { 平均粗 } \\
\text { 巳 Ra }\end{array}$ & $\begin{array}{l}\text { せん断 } \\
\text { ひ割 } \\
\text { れ強度 } \\
\left(\mathrm{N} / \mathrm{mm}^{2}\right)\end{array}$ & $\begin{array}{l}\text { 同左時 } \\
\text { せん断 } \\
\text { 変位 } \\
(\mathrm{mm})\end{array}$ & $\begin{array}{l}\text { 骨材かみ合 } \\
\text { 年開始時せ } \\
\text { h断強度 } \\
\left(\mathrm{N} / \mathrm{mm}^{2}\right) .\end{array}$ & $\begin{array}{l}\text { 同左時 } \\
\text { せん断 } \\
\text { 変位 } \\
(\mathrm{mm})\end{array}$ & $\begin{array}{c}\text { 最大せん } \\
\text { 断強度 } \\
\left(\mathrm{N} / \mathrm{mm}^{2}\right)\end{array}$ & $\begin{array}{l}\text { 同左時 } \\
\text { せん断 } \\
\text { 変位 } \\
(\mathrm{mm})\end{array}$ \\
\hline SHFP1 & 0.040 & 5.794 & 0.026 & 2.112 & 0.342 & 5.794 & 0.026 \\
\hline SHFP2 & 0.070 & 5.664 & 0.031 & 2.107 & 0.355 & 5.664 & 0.031 \\
\hline SHFP3 & 0.078 & 5.816 & 0.037 & 1.811 & 0.371 & 5.816 & 0.037 \\
\hline SHFM1 & 0.455 & 4.526 & 0.040 & 1.040 & 0.413 & 4.526 & 0.040 \\
\hline SHFM2 & 0.358 & 5.298 & 0.031 & 1.410 & 0.443 & 5.298 & 0.031 \\
\hline SA1 & $\overline{-}$ & 3.920 & 0.049 & 3.564 & 0.170 & 7.861 & 0.646 \\
\hline $\mathrm{SA2}$ & - & 4.894 & 0.032 & 4.455 & 0.060 & 6.142 & 0.692 \\
\hline SA3 & - & 4.408 & 0.063 & 4.238 & 0.059 & 7.689 & 0.430 \\
\hline SBP1 & 0.040 & 4.790 & 0.047 & 1.856 & 0.361 & 4.790 & 0.047 \\
\hline SBP2 & 0.075 & 4.630 & 0.043 & 0.701 & 0.451 & 4.630 & 0.043 \\
\hline SBP3 & 0.025 & 3.997 & 0.033 & 0.425 & 0.367 & 3.997 & 0.033 \\
\hline SBM1 & 0.435 & 5.181 & 0.031 & 2.088 . & 0.406 & 5.181 & 0.031 \\
\hline SBM2 & 0.450 & 4.986 & 0.031 & 2.409 & 0.429 & 4.986 & 0.031 \\
\hline SCP1 & 0.065 & 1.770 & 0.039 & 0.806 & 0.184 & 1.770 & 0.039 \\
\hline SCP2 & 0.045 & 2.161 & 0.029 & 0.924 & 0.144 & 2.161 & 0.029 \\
\hline SCM1 & 0.425 & 2.084 & 0.021 & 1.234 & 0.146 & 2.478 & 0.936 \\
\hline$\overline{S C M 2}$ & 0.460 & 3.151 & 0.032 & 1.864 & 0.167 & 3.151 & 0.032 \\
\hline
\end{tabular}

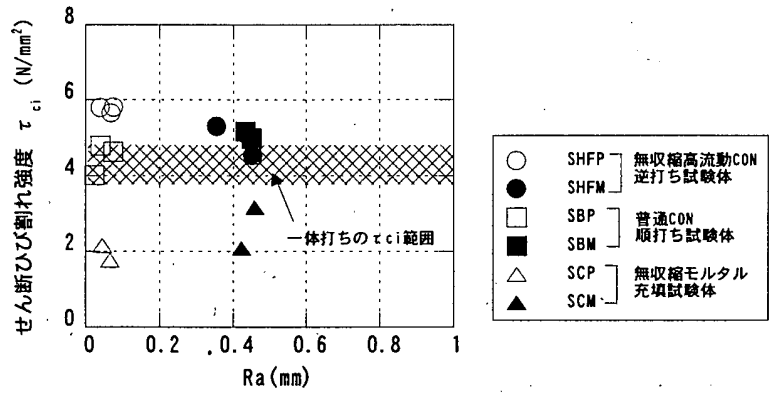

図 15 せん断ひび割れ強度 $\tau_{\mathrm{ci}}$ と表面粗さ Ra との関係

施工上の不備から無収縮モルタルの打継ぎ面への充填が不十分であ ったことが原因であると考えられる。

以上の結果から，無収縮高流動コンクリートを逆打ちした試験体 のせん断ひび割れ強度は, 普通コンクリートを順打ちした試験体と 比較すると同等以上の性能を有することが確認できた。

無収縮高流動コンクリートを逆打ちした試験体, 普通コンクリー トを順打ちした試験体および無収縮モルタルを充填した試験体の 各々のせん断ひび割れ強度と表面粗さ $\mathrm{Ra}$ の関係をみると, この実験 の範囲では表面粗さ $\mathrm{Ra}$ の程度にかかわらずせん断ひび割れ強度は ほぼ一定であった。以上から，打継ぎ部のせん断ひび割れ強度は表 面粗さ Ra の影響を受けにくいことが判った。

（3）骨材かみ合い開始時せん断強度と表面粗さ（Ra）との関係

図 16 に骨材かみ合い開始時のせん断強度 $\tau_{\mathrm{si}}$ と表面粗さ $\mathrm{Ra}$ の関係 を示す。図 17 に骨材かみ合い開始時せん断強度のせん断ひび割れ強 度に対する割合 $\tau_{\mathrm{si}} / \tau_{\mathrm{ci}}$ と表面粗さ $\mathrm{R} a$ との関係を示す。無収縮高流 


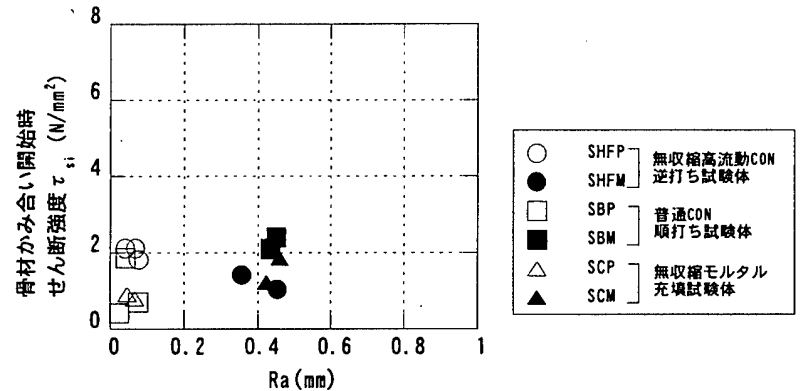

図 16 骨材かみ合い開始時のせん断強度 $\tau_{s i}$ と表面粗さRa の関係

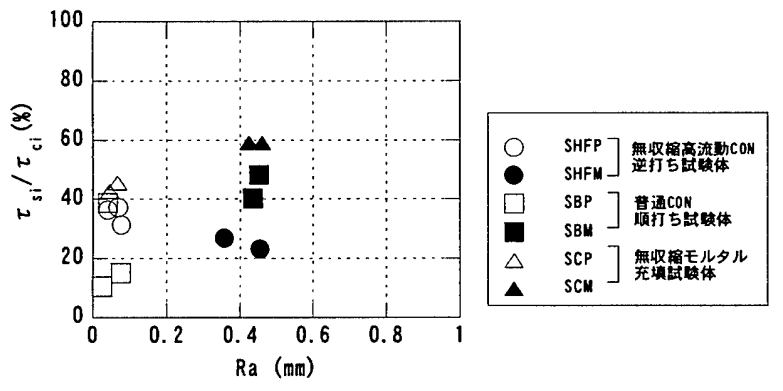

図 $17 \tau_{s i} / \tau_{c i}$ と表面粗さ $\mathrm{R}$ a との関係

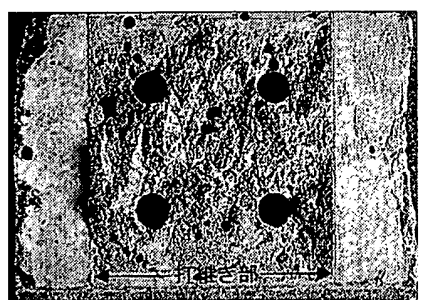

逆打ち SHFP の破面

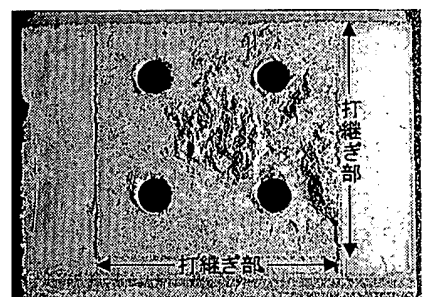

順打ち SBP の破面

\section{写真 2 破面状況の比較}

動コンクリートを平滑面に逆打ちした SHFP の骨材かみ合い開始時 のせん断強度は, 順打ちした SBP および充填法による SCP よりも少 し大きな值を示した。写真 2 に示すように SHFP の破面は SBP に比 ベ凹凸が激しく, SBP よりも打継ぎ部の一体性が高いことが判ると 同時に, 破面の凹凸が大きいため滑り破壊後の骨材かみ合い強度が 高くなったと考えられる。一方, 目荒しした面に無収縮高流動コン クリートを逆打ちした試験体 SHFM の骨材かみ合い開始時のせん断 強度は, 目荒し面に普通コンクリートを順打ちした SBM よりも少し 小さく, 無収縮モルタルの充填が不十分であった充填法による SCM とほぼ同程度であった。さらに普通コンクリートを順打ちした試験 体および無収縮モルタルを充填した試験体では，打継ぎ面が平滑な 試験体にくらべ目荒しした試験体の方が $\tau_{\mathrm{si}} / \tau_{\mathrm{ci}}$ は大きくなる傾向 がみられたのに対し, 無収縮高流動コンクリートを用いた試験体に おいては $\tau_{\mathrm{si}} / \tau_{\mathrm{ci}}$ が若干小さくなる傾向がみられた。前述のようにフ レッシュ時の膨張高さが小さいため, 目荒し面への無収縮高流動コ ンクリートの付着が不十分であったためと考えられる。以上から， 逆打継ぎ部の骨材かみ合い開始時せん断強度を順打継ぎ部と同等以 上にするには, 適切な膨張高さを確保し, 無収縮高流動コンクリー トを逆打継ぎ面に確実に付着させる必要があることが判った。

\section{(4). 今後の問題点}

今回提案したせん断試験方法によって, 無収縮高流動コンクリー トを逆打ちした打継ぎ部と各種の処理法で打継いだ打継ぎ部におけ
るせん断挙動について, 弾性変形, 滑り破壊, 骨材かみ合いの各段 階での差異を比較的適切に捕えることができた。今後は鋼棒による 拘束度の違い, 打継ぎ面の粗度, 無収縮高流動コンクリートの膨張 高さなど条件の違いによる影響をさらに検証していく必要がある。

\section{5. まとめ}

本研究から以下の知見が得られた。

（1）無収縮高流動コンクリートを平滑面に逆打ちした逆打継ぎ部は 順打継ぎ部にくらべ $\mathrm{G}_{\mathrm{F}}$ にはほとんど差が見られないが，曲げ 強度は同等以上である。

（2）無収縮高流動コンクリートを平滑面に逆打ちした逆打継ぎ部の 曲げ強度は一体打ちの 50〜60\%である。

（3）無収縮高流動コンクリートを逆打ちした試験体のせん断ひび割 れ強度は, 普通コンクリートを順打ちした試験体のせん断ひび 割れ強度と比較すると同等以上の性能を有する。

（4）今回の実験の範囲では表面粗さ $\mathrm{Ra}$ の程度にかかわらず，せん 断ひび割れ強度はほぼ一定であったため, 打継ぎ部のせん断ひ び割れ強度は, 表面粗さ Ra の影響を受けにくいと考えられる。

（5）逆打継ぎ部の骨材か夕合い開始時せん断強度を順打継ぎ部と同 等以上にするには, 適切な膨張高さを確保し, 無収縮高流動コ ンクリートを逆打継ぎ面に確実に付着させる必要がある。

（6）今回提案したせん断試験法により, 各種処理法で打継いだ打継 ぎ部でのせん断挙動について，弾性変形，滑り破壊，骨材かみ 合いの各段階での差異を比較的適切にとらえることができる。

\section{参考文献}

1）石原誠一郎, 三橋博三，立松和彦，山㟝順二：無収縮高流動コンクリート で一体化した逆打ちコンクリートの打継ぎ部せん断性状, コンクリート工 学年次論文報告集, Vol.21, No.2, pp.439 444, 1999

2) 石原誠一郎，三橋博三，立松和彦，森 浩二，山㠃順二：無収縮高流動 ンクリートで一体化した逆打ちコンクリートの打継ぎ部付着性状，日本建 築学会大会学術講演梗概集, pp.529 530, 2002.8

3）日本建箘学会：建築工事標準仕様書・同解説 JASS5 鉄筋コンクリート工 事, p.242, 2003.2

4）土木学会：コンクリート標準示方書[施工編], pp.104〜106，2000.1

5）入沢賢一，武田寿一，大内一，竹本靖：逆打工法による打継部を含む RC 柱の実験的研究，大林組技術研究所報，No.14，pp.24〜28, 1977

6)高幣喜文，耐角昌公，宮内靖昌：逆打工法における柱打継き部の力学性状 に関する実験的研究, 日本建築学会構造系論文報告集, No.393, pp.1〜10, 1988.11

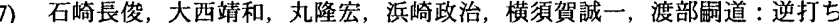
工法における打継ざ部の構造性能 （その 1$)$ 試駼体の製作，日本建築学 会大会学術講演梗概集, pp.779 780, 1996.9

8）小谷一三，中里吉明，本橋㹂一：逆巻コンクリート工法の開発研究，鹿島 建設技術研究所年報, No.31, pp.1 8, 1983.6

9）宇治公隆，松岡康訓：A1 粉末を湜入したコンクリートで一体化した逆打 ちコンクリートの打継部せん断挙動, 大成建設技術研究所報第 16 号, pp.51 $\sim 59,1983$

10）高瀨三郎，田辺清，松岡康訓：アルミニウム粉末を使用した逆打ちコンク リート，土木学会論文集，No.355/V-1，pp.63〜 71，1986.3

11) Ishihara, S., Mihashi, H., Tatematsu, K. and Yamasaki, J. : Fundamental Study on Shrinkage Compensating High Fluidity Concrete, Internationl Workshop on Control of Cracking in Early-Age Concrete, Tohoku University, Sendai, Japan, 2000.8

12）石原喊一郎，三橋博三，立松和彦，高見錦一，山㠃順二：無収縮高流動 コ ンクリートを用いた逆打ち工法の実大施工実験, 日本建築学会技術報告集, No.13, pp.19 24, 2001.7

13）日本コンクリート工学協会 : コンクリートの破塤特性の試験方法に関する調查 研究委員会報告萣, 2001.5

14）满洸利明，横関康祐，信田佳延：一軸拘束試験装置を用いた膨張材の温度 応力抑制効果に関する実験的検討，コンクリート工学年次論文報告集， Vol.20, No.2, pp.1051 1056, 1998 